\title{
Challenging and defending liquidated damages
}

\author{
by Finola O'Farrell QC
}

This article is derived from a lecture at the Annual Northern Seminar for the Society for Advanced Legal Studies on January 16, 2004. It examines the grounds on which liquidated damages provisions are open to challenge and the damages recoverable for delay where such provisions are upheld or struck down.

\section{INTRODUCTION}

$\Delta$ liquidated damages provision is a stipulation in a contract for a fixed sum to be paid as damages for breach of the contract. The purposes served by the liquidated damages provision are that the damages payable by the contract breaker (eg a contractor in delay) are limited and the innocent party (eg an employer who receives late completion) does not have to prove strictly his losses. Of commercial importance, the provision provides certainty for both parties enabling them to assess and price the risks associated with delay.

The fixed sum may be an identified amount of money or a sum ascertainable by a formula (eg £x per week). The fixed sum may apply in the event of one or more different types of breach and cover one or more different types of damage. There may be a number of separate provisions for liquidated damages in one contract.

\section{IS THE LIQUIDATED DAMAGES PROVISION AN EXHAUSTIVE REMEDY?}

Any liquidated damages provision has to be construed in the context of the contract in question as a matter of contractual interpretation. It is always open to the parties to agree expressly that any liquidated damages will or will not constitute an exhaustive remedy for the relevant breach. In the absence of such express agreement, for most building and engineering contracts the starting point is that it operates as an exhaustive remedy for damages for late completion (Cellulose Acetate v Widnes Foundry [1933] AC 20 (HL); Diestal v Stevenson [1906] 2 KB 345 (KBD)).

In Temloc v Erill Properties (1987) 39 BLR 30 (CA) Nourse LJ described the liquidated damages provision in the 1980 JCT Standard Form of Building Contract as:

"an exhaustive agreement as to the damages which are or are not to be payable by the contractor in the event of his failure to complete the works on time."

A different position appears to be taken in the case of charterparties where the courts have permitted the recovery of general damages in addition to liquidated damages. In Aktieselskabet Reidarv v Arcos Ltd [1927] 1 KB 352 (CA) the Court of Appeal allowed a claim for damages for dead freight as a result of a failure to load the cargo at the stipulated rate in addition to agreed demurrage for delay. The Judges allowed the claim on different grounds.

Bankes LJ justified the decision by identifying two separate breaches, namely (i) the failure to complete loading within the stipulated time for which demurrage was paid and (ii) the failure to load at an agreed rate for which damages were recoverable (p.362):

\begin{abstract}
"Upon the special facts of this case the plaintiffs' claim appears to me to be ... essentially distinct from any claim for detention of the vessel. In substance what the plaintiffs are saying is that if the charterers had loaded the goods at the agreed rate they would have earned freight on 850 standards, whereas owing to the failure to load at that rate they could only earn freight on 544 standards, and that their loss directly flowing from the breach of contract is the difference between the amount of freight which they would have earned and the amount which they in fact earned. This loss is, in my opinion, on the facts of this case recoverable as damages for the breach of contract to load at the agreed rate."
\end{abstract}

Atkin LJ appeared to allow the additional damages on the ground that there was one breach of contract with two parts, namely, (i) a failure to load a cargo within the stipulated time and (ii) a failure to load a full and complete cargo, and two separate heads of loss p.363:

"The result of the authorities appears to be that in a contract fixing a number of lay days and providing for days at demurrage thereafter, the charterer enters into a binding obligation to load a complete cargo within the lay days subject to any default by the shipowner... If the lay days expire without a full cargo having been loaded the charterer has broken his contract. The provisions as to demurrage quantify the damages, not for the complete breach, but only such damages as arise from the detention of the vessel..." 
The reference to an incomplete breach is surprising and not satisfactory. It is suggested that a better explanation for Atkins LJ's decision is that there were two distinct breaches: breach of the obligation to load the cargo within the stipulated time, giving rise to the agreed demurrage; and breach of the obligation to load a full and complete cargo, giving rise to damages.

Sargant LJ based his decision on the ground that there were two separate breaches, each giving rise to a separate right to damages:

"On the footing then that clause 3 of the charterparty fixes the damages for the detention of the ship at 251. a day, does the payment of a sum calculated on this basis form an agreed compensation for the loss which the owners have sustained in the circumstances of this case? I cannot think so. The loss inflicted on the owners and claimed by them is loss of another character - namely, loss of freight caused by the breach by the charterers of their contract to load a full and complete cargo as prescribed by clause 1 of the charterparty. The obligation of clause 1 is, in my judgment, rightly described by the learned judge as the primary obligation. The object of the second sentence of clause 3 is to provide compensation for a detention of the vessel in the course of fulfilling this primary obligation, not to give compensation for the breach of the primary obligation itself. No doubt the same delay in loading, which might give rise to a claim for detention, also resulted in a breach of the obligation to load a full cargo, but the breach of this latter obligation caused a definite separate loss independent of and largely exceeding any loss arising from mere detention."

This case was considered by Webster J in Total Transport v Amoco Trading ("The Altus") [1985] 1 Ll.Rep. 423 (Com.Ct), in which the owners of a vessel recovered damages for the charterers' failure to load the minimum stipulated cargo in addition to demurrage for delay. Having referred to the judgments in The Arcos Webster J stated at p 435:

"... it seems to me that I must treat the ratio decidendi of the case as being that where a charterer commits any breach, even if it is only one breach, of his obligation either to provide the minimum contractual load or to detain the vessel for no longer than the stipulated period, the owner is entitled not only to the liquidated damages directly recoverable for that breach of the obligation to load (deadfreight) or for the breach of the obligation with regard to detention (demurrage), but also for, in the first case, to the damages flowing indirectly or consequentially from any detention of the vessel (if it occurs) and, in the second case, to damages flowing indirectly or consequentially from any failure to load a complete cargo if there is such a failure."

To the extent that this case is authority for the proposition that general damages are recoverable in addition to liquidated damages for the same breach, it is based on an understandably mistaken analysis of Arcos. The charterparty cases can be explained as cases where more than one breach occurred and the loss claimed fell outside the ambit of the liquidated damages provision as a matter of construction. Reading the construction and the charterparty cases together, the position appears to be:

(1) each liquidated damages clause has to be construed in order to identify what breach and loss it is intended to cover;

(2) generally, the liquidated damages clause will be held to be an exhaustive remedy for that identified breach and loss;

(3) additional damages are recoverable provided that a separate breach and separate head of loss can be established.

\section{GROUNDS ON WHICH LIQUIDATED DAMAGES CAN BE CHALLENGED}

The grounds on which liquidated damages can be challenged can be summarised as follows:

(1) On a true construction of the provision, it is not applicable to the event that has occurred (eg no breach or different breach).

(2) There is a condition precedent to the applicability of the liquidated damages provision (eg a certificate of non-completion) that has not been satisfied.

(3) The provision is invalid or void for uncertainty.

(4) The material contractual machinery is inoperable or has broken down.

(5) The provision is a penalty.

The first two grounds are relatively straightforward as matters of construction but the other grounds have given rise to difficulties in application.

\section{Invalid or void for uncertainty}

If, on a true construction, the liquidated damages provision does not make sense and cannot be made to make sense, or is too uncertain, it will not be enforced. In Bramall \& Ogden Ltd v Sheffield City Council (1983) 29 BLR 73 (OR) the JCT Contract (1963 Edition, July 1973 Revision) provided for the contractor to construct 123 dwellings and associated works. The rate for liquidated damages in the Appendix was expressed as "at the rate of $\$ 20$ per week for each uncompleted dwelling".

There was no provision for sectional completion but as houses were completed they were taken over by the employer by consent. Clause 16(e) provided that where parts of the works were taken into possession by consent, the sum to be paid or allowed as liquidated damages should be proportionately reduced on the basis of the value of the occupied part relative to the full contract sum. The court (OR, now TCC) held that the employer was not entitled to deduct liquidated damages. The provision was held to be inoperable ("one cannot operate the Appendix and Condition 16(e)..") because of the inconsistency between clause 16(e) and the Appendix in that the calculation required in clause 
16(e) could not be carried out by reference to a rate per uncompleted dwelling rather than a specific rate for the whole of the works.

The decision was referred to with approval in Arnhold \& Co v A-GEAES of Hong Kong (1989) 47 BLR 129 (H Ct HK) where a liquidated damages provision expressed as a range of figures (without machinery to determine the precise figure) was held to be void for uncertainty.

However, a liquidated damages provision will not be held to be invalid merely because it is difficult to construe. The courts are reluctant to hold that a provision in a commercial contract is void for uncertainty or otherwise inoperable and, if the intention of the parties can reasonably be discerned from the contract and any admissible factual background, the court will give effect to that intention even where that involves departing from or qualifying the particular words used. (See Robophone Facilities Ltd v Blank [1966] 1 WLR 1428; Philips Hong Kong Ltd v AG- Hong Kong (1993) 61 BLR 41 (PC); Investors Compensation Scheme Ltd ${ }_{v}$ West Bromwich Building Society [1998] 1 WLR 896 (HL).

It is only where the provision is unworkable or too uncertain to ascertain what the parties intended that the courts will declare it to be invalid and unenforceable.

\section{Machinery inoperable or breaks down}

In construction contracts, a liquidated damages provision is usually inserted in respect of damages caused by delay in completing the works. The employer's ability to rely on such provision is lost if the employer prevents the contractor from completing by the completion date without any effective mechanism for extending time for completion. Such failure arises where:

(1) the extension of time clause does not entitle the contractor to an extension for the event that has occurred and the event is the responsibility of the employer;

(2) the extension of time clause cannot be operated effectively, eg through unfortunate drafting; or

(3) the machinery for determining extensions of time breaks down, eg where the parties have agreed a procedure that is not operated.

If the employer causes delay and there is no effective mechanism for awarding an extension of time to the contractor for such delay, the contractor is relieved of his obligation to complete by the contractual completion date (or any extended contractual date for completion) and time is at large: Wells v Army \& Navy Co-operative Society (1903) CLY 1998-1999 65 (CA); Holme v Guppy (1838) 3 M\&W 387; Amalgamated Building Contractors Ltd v Waltham Holy Cross UDC [1952] 2 All ER 452 (CA); Peak Construction (Liverpool) Ltd v McKinney Foundations Ltd (1970) 1 BLR 111 (CA); Dodd v Churton [1897] 1 QB 562 (CA).

\section{Penalty}

If a liquidated damages provision is a penalty, it will not be enforced. The basis on which a penalty will not be enforced by the courts is that it is unconscionable. The test as to whether a clause constitutes a liquidated damages provision or a penalty was set out by Lord Dunedin in Dunlop Pneumatic Tyre Co Ltd $v$ New Garage and Motor Co [1915] AC 79, p 86 and can be summarised as follows:

(1) The fact that the parties have labelled a clause "liquidated damages" or "penalty" is not conclusive.

(2) The essence of a penalty is a payment of money stipulated as in terrorem of the offending party. The essence of liquidated damages is a genuine pre-estimate of damage.

(3) The question of whether a provision amounts to a penalty or liquidated damages is a question of construction in all the circumstances of the case.

Examples of the circumstances in which a court is likely to hold that the provision is a penalty are:

(1) the sum stipulated is greater than the greatest loss that could conceivably be proved;

(2) the breach in question is the non-payment of a sum and the penalty is a greater sum;

(3) a lump sum is stipulated for a number of events that are likely to give rise to different levels of damages.

A provision will not be held to be a penalty just because it is difficult to make a pre-estimate of the loss likely to be suffered in the event of a breach. Indeed, such difficulty is often the commercial justification for agreed liquidated damages. The courts are slow to hold that a liquidated damages provision is a penalty where there is credible evidence that a genuine assessment has been made (Impresa Castelli SpA v Cola Holdings Ltd 87 Con LR 123 (TCC); City Inn v Shepherd Construction Ltd [2003] BLR 468 (Ct Sess.). However, they will not shy away from striking down provisions that are shown to be penal in nature, such as an extortionate rate of interest (Jeancharm Ltd v Barnet Football Club Ltd (2003) CILL 1987).

\section{GENERAL DAMAGES IF LIQUIDATED DAMAGES UNENFORCEABLE}

An employer is entitled to claim general damages for delay in the absence of any valid liquidated damages provision. There is no direct authority on the question whether the employer's entitlement to general damages is limited to the unenforceable liquidated damages provision. The question was expressly left open in Cellulose Acetate Silk Co Ltd v Widnes Foundry [1933] AC 20 (HL) per Lord Atkin p 26 and in Rapid Building v Ealing Family Housing (1984) 29 BLR 1 (CA).

In charterparty cases, it seems clear that the courts will disregard a penalty clause and permit the innocent party to recover its actual loss, whether more or less than the sum stipulated in the penalty clause: Wall $v$ Rederiaktiebolaget Luggude [1915] 3 KB 66 (KBD); Watts v Mitsui [1917] AC 227 (HL). However, it does not follow that the Court's approach to penalty clauses in those charterparty cases will 
be adopted in other cases. In Widnes Foundry $v$ Cellulose Acetate Silk Co [1931] 2 KB (CA) (upheld on appeal to HL) Scrutton LJ referred to Wall and Watts at p 408:

"Lord Sumner went further, and said that the clause did not prevent the shipowner or charterer from recovering the actual amount of damage, though it might be more than the estimated amount of freight. That in my view turned largely upon the fact that there was one clause purporting to fix one damage for every sort of breach."

In Robophone v Blank (supra), a case in which the Court of Appeal held that a liquidated damages provision was not a penalty, Diplock LJ raised the question but expressly did not answer it:

"Where the court refuses to enforce a 'penalty clause' of this nature, the injured party is relegated to his right to claim that lesser measure of damages to which he would have been entitled at common law for the breach actually committed if there had been no penalty clause in the contract.... I make no attempt, where so many others have failed, to rationalise this common law rule... it is by no means clear that 'penalty clauses' are simply void, like covenants in unreasonable restraint of trade. There are dicta either way, and in Cellulose Acetate Silk v Widnes Foundry Lord Atkin expressedly left open the question whether a penalty clause in a contract, which fixed a single sum as payable upon breach of a number of different terms of the contract, some of which breaches may occasion only trifling damage but others damage greater than the stipulated sum, would be treated as imposing a limit on the damages recoverable in an action for a breach in respect of which it operated to reduce the damages which would otherwise be recoverable at common law..."

This decision was treated incorrectly as authority for the proposition that general damages recovered could be greater than the amount stipulated in the penalty clause in $W \& J$ Investments Ltd v Bunting (1984) NSWLR 331 pp 335-6.

Dicta in Elsley ${ }_{v}$ Collins (1978) 83 DLR 1 (Sup Ct Canada) indicated that where a liquidated damages provision was a penalty, the party seeking general damages should be limited to recovery of the agreed sum in the liquidated damages clause but that has been explained as a reference to a limitation of liability clause as opposed to a liquidated damages clause.

In Jobson v Johnson [1989] 1 All ER 621 (CA) the plaintiff accepted the decision of Harman $\mathrm{J}$ at first instance that a clause requiring the re-transfer of shares to the plaintiff at a fixed sum in the event of a default in payments constituted a penalty. The question for the court was whether and on what basis the plaintiff should be entitled to enforce the clause given that the shares could be worth more or less than the plaintiff's actual loss and the defendant's counterclaim for relief had been struck out. Dillon LJ considered the attitude of the courts to penalty clauses and referred to section 8 of the Administration of Justice Act 1696 at p 627:
"The procedure under the section was that the plaintiff might sign judgment for the full amount of the penalty claimed, but he could not enforce the judgment by execution or otherwise without assigning or alleging the breaches of the agreement on which he relied and proving his damage from those breaches, and he could only enforce the judgment to the extent of the damage so proved... the plaintiff could not levy a default judgment for the full amount of a penalty without going to a jury to prove his actual loss."

And Nicholls LJ stated at p 633:

"Although in practice a penalty clause in a contract as described above is effectively a dead letter, it is important in the present case to note that, contrary to the submissions of counsel for the defendant, the strict legal position is not that such a clause is simply struck out of the contract, as though with a blue pencil, so that the contract takes effect as if it had never been included therein. Strictly, the legal position is that the clause remains in the contract and can be sued on, but it will not be enforced by the court beyond the sum which represents, in the events which have happened, the actual loss of the party seeking payment."

Taking into account the above authorities, the position seems to be that a distinction can be drawn between those cases in which the liquidated damages provision is struck out of the contract (and therefore the contract should be read without any reference to the clause) and those cases in which the liquidated damages provision remains part of the contract but is unenforceable:

(1) If a liquidated damages clause is a penalty, the clause remains part of the contract and an employer will be entitled to claim general damages subject to a cap at the level of damages stipulated in the contract.

(2) There are differing views on whether a liquidated damages clause is an exhaustive remedy. It is probably a matter of construction of each contract. The shipping cases can be explained on the basis that the additional damages were for different types of breach and, historically, the provisions have not been treated by the parties as providing an exclusive remedy.

(3) If a liquidated damages clause fails because it is inoperable or is void for uncertainty, it falls from the contract and the employer's entitlement to general damages will not be subject to a cap.

(4) If a liquidated damages clause fails as a result of an act of prevention by the employer, it is likely that the Courts would permit recovery of general damages but subject to the cap of the stipulated damages. The clause remains part of the contract but cannot be relied on by the employer because of the act of prevention. (There is no direct authority on this matter but this view is supported by Hudson (11th Ed), paras 10-024-10-042 and Keating (7th Ed), para 9-33). 